\title{
Study Condition Code
}

National Cancer Institute

\section{Source}

National Cancer Institute. Study Condition Code. NCI Thesaurus. Code C94086.

A coded value specifying the condition that is the focus of the study. 